\title{
HOSPITAL HEALTH SERVICE INNOVATION IN THE NATIONAL HEALTH INSURANCE ERA
}

\author{
Andika Putri'1), Wahyu Sulistiadi²) \\ 1)Masters of Public Health, Faculty of Public Health, Universitas Indonesia \\ 2)Department of Administration and Health Policy, Faculty of Public Health, \\ Universitas Indonesia
}

\begin{abstract}
Background: Hospitals have the obligation to provide quality health services, both out-patient and in-patient, at the secondary and tertiary levels. Within the current national health insurance scheme, hospitals have the opportunity to introduce innovations in the health care service delivery and its marketing, with the main objective to increase patients' outcome and satisfaction. This study aimed to investigate hospital health service innovation in the national health insurance era.

Subjects and Method: This was a qualitative study. The theme of this study was hospital health service innovation in the national health insurance era. The data were collected by in-depth interview and document review. The data were analyzed by content analysis.

Results: The national health insurance scheme allows hospitals to innovate their health services and marketing, including (1) health services are open in the morning until night and remain open on weekends; (2) health providers do not charge fees and provide extra service; and (3) patients can upgrade their class entitlement to VIP-class. Sharing the experience of health services by providing hospital recommendations to family and friends is one of the marketing strategies.

Conclusion: Hospitals have the obligation to provide quality services and satisfaction to patients. In response to the current national health insurance policy, some hospitals have made innovation in their health service delivery and marketing.
\end{abstract}

Keywords: health service, innovation, hospital, patient satisfaction

Correspondence:

Andika Putri. Magister of Public Health, Faculty of Public Health, Universitas Indonesia, Depok, West Java. Email: andika.putri@ui.ac.id. Mobile: 6281554751732.

The $6^{\text {th }}$ International Conference on Public Health

Best Western Premier Hotel, Solo, Indonesia, October 23-24, 2019 | 323

https://doi.org/10.26911/the6thicph.04.85 